\title{
COMPARING THE OUTCOMES OF ROUTINE AND SELECTIVE EPICARDIAL PACING WIRE PLACEMENT: A SINGLE-CENTER EXPERIENCE OF 237 PATIENTS
}

\author{
Emced Khalil \\ Ordu university, University education and research hospital, Ordu, Turkey
}

Primljen/Received 02. 09. 2019. god.

Abstract: Objective: Recently, the use of epicardial pacing wires (EPW) has become the standard of care for patients undergoing open-heart surgery (OHS) at many cardiovascular surgery centers. However, the routine use of EPWs after OHS is increasingly questioning due to their potentially lethal complications and limited efficacy. Here, we aimed to investigate the impact of EPW placement on in-hospital mortality and to compare the frequency of the EPW related complications in patients receiving routine or selective EPW placement after elective OHS.

Methods: A total of 237 patients undergoing OHS in our clinic (ORDU UNIVERSTY TRAİNING AND RESEARCH HOSPITAL) were enrolled in this study. Study subjects were randomly assigned to one of the groups: Routine or selective EPW placement. In the latter, EPWs were placed according to the presence of intraoperative bradycardia with hemodynamic compromise, nodal or junctional arrhythmias, atrioventricular block or ventricular tachycardia.

Results: There were 95 patients $(40 \%)$ receiving routine EPW and $142(60 \%)$ patients receiving selective EPW. Active pacing was performed or required in 13 patients (5.4\%). Five of them were in routine EPW group and 8 were in the selective EPW group $(\mathrm{p}=$ $0.902)$. Active pacing requirement was similar in coronary artery bypass grafting and valvular surgery ( $5 \%$ vs. $9 \%, p=0.712$, respectively). Permanent pacing was required in any of the subjects. Complications related to EPW occurred in 17 patients receiving routine EPW and 2 patients receiving selective EPW $(\mathrm{p}<0.001)$. Routine EPW implantation was significantly correlated with the development of the complications ( $\mathrm{r}=$ $0.309, \mathrm{p}<0.001$ ).

Conclusion: Our findings indicate that the number of patients requiring temporary pacing after $\mathrm{OHS}$ is qu-
Prihvaćen/Accepted 12. 10. 2019. god.

ite low and implementing an EPW is associated with potentially hazardous complications. Selective EPW placement compared to routine EPW placement is associated with fewer postoperative complications.

Key words: Open heart surgery, epicardial pacing wire, complication.

\section{INTRODUCTION}

Conduction disturbances due to surgical manipulations, myocardial edema, hypothermia, and cardioplegia solutionare frequently encountered following open-heart surgery (OHS) (1). Many of the patients undergoing open-heart surgery, therefore, receive epicardial pacing wires (EPW) to avoid unforeseen complications such as conduction disturbances. Overdrive pacing or electrical cardioversion applied through EPWs might also be useful in the treatment of atrial and ventricular tachyarrhythmia developing after $\operatorname{OHS}(2,3)$.

During the procedure, pacing electrodesare loosely sutured onto the epicardial surface of the right ventricle and/or right atrium and are approximated to the skin through the anterior chest wall before chest closure (4). These wires remain on the epicardial surface for several days and are then removed if stable cardiac conduction has been established.

The use of EPWs has become the standard of care for patients undergoing OHS in many cardiovascular surgery centers. Although the efficacy of implanting an EPW has been established in patients undergoing valvular operations (5), the routine use of EPWs after OHS is increasingly being questioned due to potentially lethal complications and the limited efficacy of EPWs in coronary artery bypass grafting (CABG). In addition, implementation of EPWs as a routine procedure increases the risks for several complications in- 
cluding hemothorax, tamponade due to atrial and/or ventricular lacerations, saphenous vein graft injury, and unsuccessful removal of wiring (retained wire). These potentially lethal complications discourage surgeons when considering routine EPW placement in subjects with a lower risk for conduction abnormalities (6-9).

The purpose of the present study was to investigate the impact of EPW placement on in-hospital mortality and to compare the frequency of EPW related complications in patients receiving routine or selective EPW placement after elective OHS.

\section{MATERIAL AND METHODS}

The present study was conducted on adult patients ( $>18$ years) referred to a tertiary center for OHS between January 2018 and August 2018. A preoperative 12-lead electrocardiogram was used to identify preexisting conduction problems. Patients requiring emergent surgery and those with atrioventricular conduction abnormalities at admission were not included in this study. No patients were excluded on the basis of coronary anatomy, the number of grafts needed, or ventricular function. Informed consent was obtained from all patients and the study protocol was approved by the Institutional Ethical Committee (no:2018-e.1800178793). All surgical procedures were performed by the same surgical team and all EPWs were implanted by the same primary surgeon. Study subjects were randomly assigned to one of the groups: 1) The routine EPW group consisted of patients receiving an EPW independent of the clinical implication, 2) The selective EPW group was comprised of patients who received EPW immediately prior to chest closure as per the surgeon's discretion with regard to the occurrence of any of the following conditions: bradycardia with hemodynamic compromise, nodal or junctional arrhythmia, atrioventricular block, or ventricular tachycardia. All procedures were carried out with a median sternotomy with cardiopulmonary bypass. Moderate systemic hypothermia $\left(32^{\circ} \mathrm{C}\right)$ and topical cardiac hypothermia were used to reduce the temperature. Antegrade blood cardioplegia was used in the majority of the procedures. Data regarding age, sex, medical history electrocardiographic data and echocardiographic data (left ventricular ejection fraction[LVEF]), were collected prospectively for all patients. EPWs (Johnson \& Johnson, Somerville, NJ) were sutured either on the ventral or on the diaphragmatic surface of the right ventricle. Dopamine ( $4 \mathrm{mg} / \mathrm{kg} / \mathrm{min}$ ) was administered toward the end of cardiopulmonary bypass to improve ventricular function and enhance atrioventricular conduction, in all patients. Intraoperative details and EPW related complications were monitored for all patients throughout their hospitalization.
Temporary venous pacing equipment was on stand-by during the in-hospital course of patients that were deemed to be candidates for temporary pacing during their postoperative course. ECGs were obtained every 12 hours postoperatively and evaluated by two independent blinded cardiologists, for pacing requirement.

\section{Statistical analysis}

Statistical analyses were carried out using SPSS for Windows, version 17 (SPSS, Chicago, IL, USA). The normal distribution of continuous variables was studied with the Kolmogorov-Smirnov test. Continuous variables are presented as mean \pm standard deviation and categorical variables as a percentage. For group comparisons, the Student t-test was used for continuous variables, and Chi-square tests were used for categorical variables. Pearson and Spearman correlation analyses were performed to identify the variables that were significantly associated with pacing requirements. A p-value lower than 0.05 was accepted to be statistically significant.

\section{RESULTS}

A total of 237 patients (mean age $59 \pm 11$ years, 64 $\%$ male) undergoing OHS at our clinic were enrolled in this study. There were 95 patients $(40 \%)$ receiving routine EPW and $142(60 \%)$ patients receiving selective EPW. In the selective EPW group, 12 of the subjects received an EPW due tothe intraoperative presence of conduction disturbances or ventricular tachycardia. There were no significant differences between the two groups with respect to age, sex, preoperative atrial fibrillation, smoking, diabetes and LVEF value (Table 1).

The two groups were similar with respect to cross-clamp time, by-pass time, inotrope requirement and the type of operation performed. Active pacing was performed in 13 patients (5.4\%). Five of these patients were in the routine EPW group and 8 were in the selective EPW group $(p=0.902)$. Active pacing requirement was similar in $\mathrm{CABG}$ and valvular surgery $(5 \%$ vs. $9 \%, p=0.712$, respectively). Temporary transvenous pacing was performed only in 3 subjects in the selective EPW group due to the postoperative occurrence of advanced AV conduction. Permanent pacing was not required in any of the subjects (Table 2). Complications related to EPW occurred in 17 patients receiving routine EPW and 2 patients receiving selective EPW (p $<0.001)$. The majority of EPW related complications in the routine EPW group were associated with bleeding during EPW implantation and all were controlled with standard measures and resolved spontaneously. Cardiac tamponade developed in 2 patients and 1 pati- 
Table 1. Demographic features and LVEF values of the study population

\begin{tabular}{|l|c|c|c|}
\hline & $\begin{array}{c}\text { Routine EPW } \\
\mathbf{n = 9 5}\end{array}$ & $\begin{array}{c}\text { Selective EPW } \\
\mathbf{n}=\mathbf{1 4 2}\end{array}$ & p value \\
\hline Age (years) & $60 \pm 9$ & $58 \pm 11$ & 0.340 \\
\hline Sex (male) & $63(66 \%)$ & $89(63 \%)$ & 0.584 \\
\hline Atrial Fibrillation (n) & $8(8 \%)$ & $11(8 \%)$ & 0.852 \\
\hline Diabetes (n) & $37(39 \%)$ & $69(48 \%)$ & 0.182 \\
\hline Smoking (n) & $61(64 \%)$ & $90(63 \%)$ & 0.972 \\
\hline LVEF (\%) & $47 \pm 6$ & $48 \pm 6$ & 0.212 \\
\hline
\end{tabular}

Data are presented as mean \pm standard deviation. EPW: epicardial pacing wire, LVEF: left ventricular ejection fraction

Table 2. Intraoperative details, pacing requirement and complications in regard to groups

\begin{tabular}{|l|c|c|c|}
\hline & $\begin{array}{c}\text { Routine EPW } \\
\mathbf{n = 9 5}\end{array}$ & $\begin{array}{c}\text { Selective EPW } \\
\mathbf{n = 1 4 2}\end{array}$ & p value \\
\hline Cross-clamp time (minutes) & $59 \pm 10$ & $58 \pm 12$ & 0.418 \\
\hline By-pass time (minutes) & $108 \pm 17$ & $105 \pm 11$ & 0.068 \\
\hline Surgical procedure & & & \\
CABG (n) & $85(89 \%)$ & $118(83 \%)$ & 0.263 \\
MVS (n) & $7(7 \%)$ & $12(8 \%)$ & 0.764 \\
AVR (n) & $2(2 \%)$ & $8(6 \%)$ & 0.185 \\
\hline Ascending Aorta Surgery (n) & $1(1 \%)$ & $4(3 \%)$ & 0.354 \\
\hline Inotrope duration (hours) & $48 \pm 12$ & $50 \pm 15$ & 0.658 \\
\hline EPW implantation (n) & $95(100 \%)$ & $12(8 \%)$ & $<0.001$ \\
\hline Requirement for active pacing (n) & $5(5 \%)$ & $8(6 \%)$ & 0.902 \\
\hline Complications (n) & $17(18 \%)$ & $2(1 \%)$ & $<0.001$ \\
Bleeding (n) & $14(15 \%)$ & $2(1 \%)$ & $<0.001$ \\
Tamponade (n) & $2(2 \%)$ & 0 & 0.055 \\
Reopening (n) & $1(1 \%)$ & 0 & 0.176 \\
\hline Mortality (n) & $4(4 \%)$ & $6(4 \%)$ & 0.987 \\
\hline
\end{tabular}

Data are presented as mean \pm standard deviation.AVR: aortic valve replacement, EPW: epicardial pacing wire, MVS: mitral valve surgery

ent underwent reopening in the routine EPW group. In the postoperative period, 5 deaths were encountered in the routine EPW group and 6 deaths in the selective EPW group ( $p=0.987$, Table 2). Furthermore, there was a low but significant correlation between routine EPW implantation and complication development $(\mathrm{r}=$ $0.309, \mathrm{p}<0.001)$.

\section{DISCUSSION}

The present study aimed to investigate whether EPW placement has any impact on in-hospital mortality or development of EPW related complications in patients undergoing OHS. Our findings demonstrate that the mortality rate is similar in patients receiving routine or selective EPW placement. Moreover, EPW related complications are fewer in patients undergoing selective EPW placement. Our results also show that only a small proportion of patients, particularly those undergoing valvular surgery, require temporary pacing which indicates that the avoidance of routine EPW placement in patients undergoing CABG should be considered.

Placement of EPW onto the atrial or ventricular epicardial surface has become a standard procedure in many surgical centers since its introduction in the1960's (10). Surgical manipulations and tissue edema occurring after heart surgery may predispose myocardial tissue to transient conduction and rhythm disturbances which commonly develop after the release of the aortic cross-clamp $(11,12)$. Placement of an EPW constitutes a simple and effective method in the treat- 
ment of various conduction disorders that occur after cardiac surgery $(13,14,15)$. However, with the advance in surgical techniques and the equipment used in these procedures, open heart surgery is currently less time consuming and tissue manipulation is less prominent, which has led clinicians to question the necessity of routine EPW placement. The most common type of conduction disturbance after OHS is reportedly sinus bradycardia which very rarely warrants the use of temporary pacing in the presence of other options. In a recent trial conducted on 374 patients undergoing OHS, the development of second and third-degree atrioventricular block which usually necessitates temporary pacing was observed in only $7.3 \%$ of the subjects, most commonly in those undergoing valvular operations (16). Similar to these findings, in a study of 564 patients undergoing CABG and receiving an EPW according to the intraoperative presence of conduction disturbances, the authors reported that $5.5 \%$ of patients received EPWs intraoperatively and only 3 patients who had not received EPWs further required temporary transvenous pacing (17). In another large prospective cohort study of 1047 patients undergoing CABG, 770 of the subjects received an EPW before the completion of the surgery, and complete AV block requiring ventricular pacing developed in only two patients (18). These studies recognized that routine EPW placement is not required after $\mathrm{CABG}$.

In addition, the short-term reliability of EPW placement might be limited due to wire dislodgement or failure of AV sensing and increasing capture thresholds (19). Moreover, some rare but potentially hazardous complications associated with EPWs including cardiac strangulation, lacerations to coronary grafts or ventricles, hemothorax, tamponade and infections related to retained wires have been reported $(20,21)$. In a review written by Khorsandi et al., the authors stated that the overall rate of complete AV block was around $2.4 \%$ in OHS. This finding shows that only 1 out of 42 routinely-placed EPWs are instrumental in preventing a complete heart block, which warrants the implementation of measures to reduce the number of EPWs used after OHS. Therefore, we believe surgeons should perform a meticulous evaluation of risk factors and should weigh the benefits against risks when making the deci- sion for EPW placement in order to prevent potential complications (22).

Our findings confirm that routine EPW placement is associated with a high frequency of EPW related complications which are potentially lethal. In our study, the active pacing requirement was relatively low $(5 \%)$, similar to previous reports. The routine administration of inotropic agents towards the end of the procedure might have decreased the incidence of sinus bradycardia and first-degree atrioventricular block. With this background in mind, we believe that the routine implementation of EPWs in patients undergoing OHS has no advantage over the selective approach. Meticulous intraoperative monitoring and placement of EPWs with evidence of intraoperative conduction and rhythm disturbances might prevent the overuse of EPWs and thus complications related to EPWs.

\section{CONCLUSION}

In summary, our results indicate that the number of patients requiring temporary pacing after $\mathrm{OHS}$ is quite low and routine EPW placement is associated with increased complications. Selective EPW placement compared to routine EPW placement is associated with fewer postoperative complications. Therefore, we suggest the utilization of EPWs only in patients experiencing intraoperative conduction disturbances and using transvenous pacemakers when necessary in the remaining patients.
Abbreviations
EPW - epicardial pacing wires
OHS - open heart surgery
CABG - coronary artery bypass grafting
LVEF - left ventrikul ejection fraction

Conflict of Interests: The authors declare that there are no conflicts of interest related to this article.

Funding: None

\section{Licensing}

This work is licensed under a Creative Commons Attribution 4.0 International (CC BY 4.0) License. 


\title{
Sažetak \\ POREĐENJE REZULTATA RUTINSKOG I SELEKTIVNOG POSTAVLJANJA EPIKARDIJALNOG PEJSINGA: ISKUSTVAJEDNOG CENTRA OD 237 PACIJENATA
}

\author{
Emced Khalil
}

Ordu university, University education and research hospital, Ordu, Turkey

Cilj: U poslednje vreme je u mnogim centrima za kardiovaskularnu hirurgiju upotreba epikardijalnog pejsinga postala standard nege za pacijente koji su podvrgnuti operaciji na otvorenom srcu. Međutim, rutinska upotreba EPW-a nakon operacije na otvorenom srcu se sve više dovodi u pitanje zbog svojih potencijalno smrtonosnih komplikacija i ograničene efikasnosti. Ovde smo želeli da istražimo uticaj EPW na bolnički mortalitet i da uporedimo učestalost komplikacija povezanih sa EPW kod pacijenata koji dobijaju rutinski ili selektivni EPW nakon elektivne operacije na otvorenom srcu.

Metode: Ukupno 237 pacijenata koji su bili podvrgnuti operaciji na otvorenom srcu u našoj klinici (Univerzitetska bolnica za obuku i istraživanje Ordu) bilo je uključeno u ovo istraživanje. Ispitanici iz istraživanja bili su nasumično raspoređeni u jednu od grupa: rutinski ili selektivni EPW plasman. U poslednjoj, EPW su postavljani prema prisustvu intraoperativne bradikardije sa ugroženom hemodinamikom, nodalnim ili junkcionim aritmijama, atrioventrikularnim blokom ili ventrikularnom tahikardijom.

\section{REFERENCES}

1. Chua J, Schwarzenberger J, Mahajan A. Optimization of pacing after cardiopulmonary bypass. J Cardiothorac Vasc Anesth. 2012; 26(2): 291-301.

2. Liebold A, Wahba A, Birnbaum DE. Low-energy cardioversion with epicardial wire electrodes: a new treatment of atrial fibrillation after open-heart surgery. Circulation. 1998; 98(9): 883-6.

3. De Belder MA, Malik M, Ward DE, Camm AJ. Pacing modalities for tachycardia termination. Pacing Clin Electrophysiol. 1990; 13(2): 231-48.

4. Reade MC. Temporary epicardial pacing after cardiac surgery: a practical review: part 1: general considerations in the management of epicardial pacing. Anesthesia. 2007; 62(3): 264-71.

5. Puskas JD, Sharoni E, Williams WH, Petersen R, Duke $\mathrm{P}$, Guyton RA. Is routine use of temporary epicardial pacing wires necessary after either OPCAB or conventional CABG/CPB? Heart Surg Forum. 2003; 6(6): E103-6.

6. Reade MC. Temporary epicardial pacing after cardiac surgery: a practical review. Part 2: Selection of epicardial pacing modes and troubleshooting. Anesthesia. 2007; 62(4): 364-73.

7. Worth PJ, Conklin P, Prince E, Singh AK. Migration of retained right ventricular epicardial pacing wire into the pulmonary artery: a rare complication after heart surgery. J Thorac Cardiovasc Surg. 2011; 142(3): e136-8.
Rezultati: 95 pacijenata (40\%) je dobilo rutinski EPW, a 142 (60\%) selektivni EPW. Aktivni pejsing je izvršen ili bio neophodan kod 13 pacijenata $(5,4 \%)$. Pet njih je bilo u rutinskoj EPW grupi, a osam u selektivnoj $(\mathrm{p}=0.902)$. Zahtevi za aktivnim pejsingom su bili slični kod bajpasa koronarnih arterija i operaciji zalistaka (5\% naspram 9\%, p =0,712). Komplikacije povezane sa EPW zabeležene su kod 17 pacijenata koji su dobili rutinski EPW i dva pacijenta koji su dobili selektivni EPW ( $p<0.001)$. Rutinska implementacija EPW-a je bila značajno povezana sa razvojem komplikacija $(r=0.309, \mathrm{p}<0.001)$.

Zaključak: Naši nalazi pokazuju da je broj pacijenata kojima je potreban privremeni pejsing nakon operacije na otvorenom srcu prilično nizak i da je primena EPW-a povezana sa potencijalno opasnim komplikacijama. Selektivno postavljanje EPW-a u poređenju sa rutinskim povezano je sa manjim brojem postoperativnih komplikacija.

Ključne reči: operacija na otvorenom srcu, epikardijalni pejsing, komplikacija.

8. Juchem G, Golczyk K, Kopf C, Reichart B, Lamm P. Bizarre case of migration of a retained epicardial pacing wire. Europace. 2008; 10(11): 1348-9.

9. Price C, Keenan DJ. Injury to a saphenous vein graft during removal of a temporary epicardial pacing wire electrode. Br Heart J. 1989; 61(6): 546-7.

10. Willman VL, Howard H, Riberi A, Cooper T, Hanlon CR. Surgical heart block. Influence of electrical pacing, cardiotonic drugs, and body temperature. Arch Surg. 1961; 83: 496-501.

11. Pianta RM, Ferrari AD, Heck AA, Ferreira DK, Piccoli Jda C, Albuquerque LC, et al. Atrioventricular block in coronary artery bypass surgery: perioperative predictors and impact on mortality. Rev Bras Cir Cardiovasc. 2015; 30(2): 164-72.

12. Ferrari AD, Sussenbach CP, Guaragna JC, Piccoli Jda C, Gazzoni GF, Ferreira DK, et al. Atrioventricular block in the postoperative period of heart valve surgery: incidence, risk factors, and hospital evolution. Rev Bras Cir Cardiovasc. 2011; 26(3): 364-72.

13. Alwaqfi NR, Ibrahim KS, Khader YS, Baker AA. Predictors of temporary epicardial pacing wires use after valve surgery. J Cardiothorac Surg. 2014; 9:33.

14. Lazarescu C, Mertes PM, Longrois D. [Temporary epicardial pacing following cardiac surgery: practical aspects]. Ann Fr Anesth Reanim. 2013; 32(9): 592-601.

15. Aser R, Orhan C, Niemann B, Roth P, Perepelitsa A, Attmann $\mathrm{T}$, et al. Temporary epicardial pacemaker wires: the 
significance of position and electrode type. Thorac Cardiovasc Surg. 2014; 62(1): 66-9.

16. Emkanjoo Z, Mirza-Ali M, Alizadeh A, Hosseini S, Jorat MV, Nikoo MH, et al. Predictors and frequency of conduction disturbances after open-heart surgery. Indian Pacing Electrophysiol J. 2008; 8(1): 14-21.

17. Imren Y, Benson AA, Oktar GL, Cheema FH, Comas $\mathrm{G}$, Naseem $\mathrm{T}$. Is the use of temporary pacing wires following coronary bypass surgery really necessary? J Cardiovasc Surg (Torino). 2008 ; 49(2): 261-7.

18. Asghar MI, Khan AA, Iqbal A, Arshad A, Afridi I. Placing epicardial pacing wires in isolated coronary artery bypass graft surgery - a procedure routinely done but rarely beneficial. J Ayub Med Coll Abbottabad. 2009; 21(1): 86-90.
19. Elmi F, Tullo NG, Khalighi K. Natural history and predictors of temporary epicardial pacemaker wire function in patients after open-heart surgery. Cardiology. 2002; 98(4): 175-80.

20. Alhuzaimi A, Roy N, Duncan WJ. Cardiac strangulation from epicardial pacemaker: early recognition and prevention. Cardiol Young. 2011; 21(4): 471-3.

21. Del Nido P, Goldman BS. Temporary epicardial pacing after open-heart surgery: complications and prevention. J Card Surg. 1989; 4(1): 99-103.

22. Khorsandi M, Muhammad I, Shaikhrezai K, Pessotto R. Is it worth placing ventricular pacing wires in all patients post-coronary artery bypass grafting? Interact Cardiovasc Thorac Surg. 2012; 15(3): 489-93.

\section{Correspondence to/Autor za korespondenciju}

Emced Khalil. Cardiovascular surgeon

Bucak Mh. Nefsi Bucak Cad. Ordu Üniversitesi Eğitim Araştırma Hastanesi

No: 94/1 Pk: 52200 Ordu / Altınordu

Telefon: (0452) 2250185

Fax: (0452) 2250190

E-mail: emjedkhalil@gmail.com

TEL. NO: 0(505)2401565 